\title{
Reformulasi Regulasi Radio Komunitas di Indonesia
}

\author{
Kartika Sari Yudaninggar \\ Program Sarjana Ilmu Komunikasi Fakultas Ekonomi dan Sosial \\ Universitas Amikom Yogyakarta \\ kartikaninggar@amikom.ac.id
}

\begin{abstract}
Community Radio (CR) in Indonesia has emerged as a media that able to disseminate information to audience. Since this function can not be fullfiled by both private and public radios, CR is important for audience especially for those who lives in remote or even blank spot area. However, Government regulation on $C R$ is feared to deprive the existence of $C R$. The regulation ranging from limitation of frequency allocation, criteria on coverage area and limited emmitance strength compare to public and private radios. This imply that the Government has never supported the existence of Community Radio. Government and Indonesia Broadcasting Commistion (KPI), as the powerful bodies, ought to reevaluate broadcasting regulation especially on Community Radio. Reformulation on the regulation is needed to maximilize the function of $C R$ in Indonesia as independent media and to support democratization in the broadcasting system in Indonesia.
\end{abstract}

Keywords: community radio, radio, regulation

\section{Pendahuluan}

Radio sebagai salah satu media penyiaran merupakan salah satu alat komunikasi yang memegang peranan penting.Media penyiaran sejatinya adalah ruang publik, karena memiliki akses yang nyaris tanpa batas pada kehidupan publik, berinteraksi dengan bermacam kepentingan publik dan menggunakan ranah milik publik berupa spektrum frekuensi yang sistem alokasinya tebatas (Masduki, 2003: 20). Radio sebagai salah satu alat komunikasi memegang peranan penting dalam menyebarluaskan informasi, sehingga mendapat julukan sebagai 'the fifth estate' setelah pers yang disebut sebagai 'the fourth estate' (Sufi,1999: 11). Televisi yang juga termasuk salah satu media penyiaran dianggap lebih lengkap dan sempurna dibandingkan dengan radio karena televisi terdiri dari audio dan visual.Namun, televisi tidak mendapat julukan seperti yang diberikan kepada radio.

Radio dianggap sebagai teknologi komunikasi yang murah dan sederhana sehingga bisa menjangkau penduduk di pedesaan (Rachmatie, 2007: 3). Melihat kondisi geografis Indonesia yang sangat luas terdiri dari ratusan pulau, radio menjadi media yang paling 
berpotensi untuk dapat menjangkau hingga blank spot atau wilayah terluar Indonesia sekalipun.Radio komunitas di Indonesia menjadi salah satu perkembangan baru di dunia penyiaran pada awal tahun 2000-an.

Istilah radio komunitas mulai berkembang sekitar tahun 2002 yang diawali oleh sebuah radio komunitas di wilayah Yogyakarta, yaitu Radio Komunitas Angkringan. Radio ini dikelola sendiri oleh warga Timbulharjo, dan kemudian menginspirasi kelompok komunitas lain untuk turut mendirikan radio komunitas mereka, sebut saja Panagati FM, Radio Komunitas Cibangkong (RKC) di Bandung, Majalaya Sejahtera (MASE), dan radio komunitas Kamal Muara di Jakarta (http://jrki.wordpress.com/about/, diakses 27 November 2018).

Jumlah radio komunitas di Indonesia semakin bertambah dan meluas hingga 17 provinsi di Indonesia (http://jrki.or.id/?page_id=13, diakses 27 November 2018). Hal tersebut terjadi karena ada banyak keunggulan radio komunitas dibanding media konvensional.Pertama, radio komunitas mampu memenuhi kebutuhan spesifik dari kelompok masyarakat yang membentuknya. Kedua, dapat memenuhi hak informasi dan komunikasi dari kelompok marjinal, seperti perempuan, buruh, nelayan, dan kaum miskin kota. Ketiga, radio komunitas dapat mengatasi masalah keterbatasan jangkauan media konvensionalyang terpusat hanya di kota-kota besar (Dwiana, 2013: 118).
Perkembangan radio komunitas tidak berjalan mulus seperti radio swasta.Radio komunitas dianggap radio illegal dan pengganggu frekuensi. Namun, kini makna radio komunitas menurut UU Penyiaran No 32 th 2002 pasal 21 adalah lembaga penyiaran berbentuk badan hukum Indonesia, didirikan oleh komunitas tertentu, bersifat independen, dan tidak komersial, dengan daya pancar rendah, luas jangkauan wilayah terbatas, serta untuk melayani kepentingan komunitasnya.

$$
\text { Masduki, dalam bukunya }
$$
menyampaikan bahwa kekhawatiran terhadap kebangkrutan media sebagai ruang publik (public sphere) memuncak ketika terjadi perdebatan dalam perumusan UU Penyiaran pengganti UU 24/1997 di DPR.Berbagai regulasi yang membahas mengenai penyiaran baik Undang-undang Nomor 32 tahun 2002 tentang Penyiaran, Peraturan Pemerintah, peraturan menteri dan atau peraturan-peraturan lain, dianggap masih belum cukup memberikan perlindungan terhadap publik. Oleh karena itu, sejumlah aktivis penyiaran dalam Forum Diskusi Publik menyatakan bahwa perlu dilakukan perubahan mendasar, agar dunia penyiaran di Indonesia lebih sehat (Zak, 2013).Ditulis juga oleh Masduki dalam bukunya, bahwa pada prinsipnya, semua bentuk lembaga penyiaran berhak mengisi ruang frekuensi, sejauh memenuhi tiga komponen, yaitu pemenuhan kesenangan publik (public convienence), pemenuhan kepentingan publik (public interest), dan pemenuhan hak publik (public necessity) 
(Masduki, 2003: 21). Radio komunitas dapat memenuhi ketiga komponen tersebut, namun jumlah alokasi frekuensi yang diatur dalam Undang-Undang dirasa sangat kurang untuk radio komunitas.Reformulasi regulasi perlu dilakukan karena adanya sistem kepenyiaran yang memberikan hak warga negara dalam pengelolaan penyiaran merupakan hal yang penting, selain itu media merupakan domain publik, bukan milik negara ataupun perorangan.

Dalam artikel ini akan membahas mengenai radio komunitas, konvergensi radio komunitas, regulasi radio komunitas, dan reformulasi regulasi mengenai radio komunitas di Indonesia.Selain itu, artikel ini juga membahas mengenai lemahnya regulasi penyiaran, khususnya yang berkaitan dengan siaran radio komunitas, serta beberapa ide untuk reformulasi regulasi tersebut.

\section{Pembahasan}

\section{A. Radio Komunitas}

Menurut rumusan Jaringan Radio Komunitas Yogyakarta (JRKY), dalam istilah komunitas melekat dua makna, yaitu geografis dan kepentingan. Di mana dalam istilah geografis dapat dikaitkan dengan jangkauan wilayah siar, sedangkan istilah makna kepentingan masih dalam perdebatan karena kategori 'kepentingan' sangat abstrak dan cepat berubah (Masduki, 2003: 90). McQuail menyampaikan serangkaian ide dasar mengenai tujuan media dalam masyarakat, yaitu informasi, korelasi, kesinambungan,hiburan, dan mobilisasi(McQuail, 2004: 70).Sedangkan tujuan media komunitas menurut Denis McQuail adalah (1) memberikan pelayanan informasi isuisu dan problem universal, tidak sektoral dan primordial, (2) pengembangan budaya interaksi yang pluralistik, (3) penguatan eksistensi kelompok minoritas dalam masyarakat, (4) bentuk fasilitasi atas proses menyelesaikan masalah menurut cara pandang lokal (McQuail dalam Masduki 2004). Radio menjadi media yang paling berpeluang memenuhi tujuan-tujuan media komunitas tersebut, khususnya di Indonesia yang wilayahnya sangat luas dan berupa negara kepulauan.

Perbedaan antara radio komunitas dengan radio komersial terutama terlihat pada jangkauan wilayah siar dan sumber dana operasional. Pada radio komunitas, memiliki jangkauan wilayah siar yang terbatas, dengan sumber dana swadaya anggota komunitas atau mendapat subsidi. Lain halnya dengan radio komersial yang memiliki jangkauan wilayah siar lebih luas, biasanya dapat menjangkau dalam cakupan satu kota, dan sumber dana diperoleh dari iklan komersial. 
Tabel 1

Perbedaan Radio Komunitas dengan Radio Komersial

\begin{tabular}{|l|l|l|}
\hline & \multicolumn{1}{|c|}{ Radio Komunitas } & \multicolumn{1}{c|}{ Radio Komersial } \\
\hline Daerah & Kawasan khusus, terpencil & Kota utama, jumlah populasi besar \\
\hline Tujuan & $\begin{array}{l}\text { Pengembangan pendidikan } \\
\text { kepentingan komunitas) }\end{array}$ & Keuntungan \\
\hline Pemilikan & Komunitas & Pengusaha, politikus \\
\hline Manajemen & Badan komunitas media & Direktur utama \\
\hline Durasi siaran & Pendek/ terbatas & Ekstensif/ penuh \\
\hline Staf penyiar & Sukarelawan (Volunteer) & Profesional \\
\hline Transmitter & Kekuatan rendah (20-100w) & 1 Kw - 5 Kw \\
\hline Fasilitas & Sederhana & Canggih/ Modern \\
\hline Sumber dana & $\begin{array}{l}\text { Bantuan komunitas (Swadaya), } \\
\text { Subsidi }\end{array}$ & Iklan komersial \\
\hline Partisipasi & Tinggi & Rendah \\
\hline Bentuk & Demokratis, terbuka & Mengikuti aturan ekonomi politik \\
\hline
\end{tabular}

Sumber: (Pandjaitan dalam Masduki 2003: 88)

Penyiaran komunitas memiliki

manfaat bagi sistem penyiaran nasional yang bersifat positif sesuai dengan bahasan Ishadi (2004) yang dikutip oleh Rachmatie, menyebutkan bahwa kehadiran media komunitas secara fisik adalah: (1) dapat mengisi blank spot penyiaran; (2) bisa menjadi pendukung penyiaran nasional; (3) dapat menjadi sumbersumber dari acara-acara yang diangkat pada tataran lokal maupun nasional (Rachmatie, 2007: 55).Edwin Jurriëns dalam jurnalnya menyatakan bahwa fungsi utama radio komunitas adalah: merepresentasikan, mendukung budaya dan identitas lokal, menciptakan berbagai pendapat dan opini di udara, menyediakan varietas program acara, mendorong demokrasi dan dialog terbuka, mendukung pembangunan dan perobahan sosial, mempromosikan civil society, mengedepankan ide tentang good governance, mendorong partisipasi melalui membagi informasi dan inovasi, memberikan suara kepada mereka yang tidak memiliki suara, menyediakan pelayanan sosial sebagai pengganti telepon, menyumbangkan pada keberagaman dalam kepemilikan siaran, dan mengembangkan sumber daya manusia untuk industri siaran (Fraser dan Estrada dalam Jurriëns, 2003: 118).

$$
\text { Sedangkan manfaat media }
$$

komunitas bagi anggota komunitasnya sendiri, dikemukakan oleh Ishadi (2004 dalam (Rachmiatie, 2007: 56), antara lain adalah: (1) sebagai komunikasi internal di lingkungan 
komunitas; (2) komunikasi anggota komunitas dengan warga di luar komunitas atau dengan komunitas lain; (3) sebagai sarana penggerak inovasi sosial budaya dan bisnis; (4) sebagai sarana sosial kontrol; (5) sebagai sarana pendidikan umum dan agama.

Media komunitas memiliki unsurunsur yang berbeda dengan media massa konvensional. Diantaranya adalah mengenai tujuan, konten, serta karakteristiknya, dimana media komunitas lebih bersifat terbatas dan berorientasi kepada pendengar atau anggota komunitas mereka masing-masing.Dalam tabel berikut terdapat beberapa unsur yang memperjelas perbedaan media konvensional dan media komunitas.

Tabel 2

Perbedaan Media Massa Konvensional dan Media Komunitas

\begin{tabular}{|c|c|c|}
\hline Unsur-unsur & Media Massa Konvensional & Media Komunitas \\
\hline Kepemilikan & Kelompok, negara, perorangan. & Warga komunitas. \\
\hline Tujuan dan Sasaran & $\begin{array}{l}\text { Informasi, hiburan, pendidikan dan } \\
\text { kepentingan komersial/bisnis. } \\
\text { Khalayak luas, publik sasaran khusus, } \\
\text { klien. }\end{array}$ & $\begin{array}{l}\text { Informasi, pendidikan. } \\
\text { Bimbingan, hiburan tetapi tidak } \\
\text { komersial/ mencari laba. } \\
\text { Komunitas yang bersifat terbatas. }\end{array}$ \\
\hline Content/ isi & $\begin{array}{l}\text { Aneka informasi yang bersifat } \\
\text { universal, menyentuh kepentingan } \\
\text { berbagai segmentasi khalayak. } \\
\text { Isi dirancang oleh lembaga media. }\end{array}$ & $\begin{array}{l}\text { Informasi yang terpilih sesuai } \\
\text { dengan kondisi dan kepentingan } \\
\text { komunitas. } \\
\text { Isi dirancang oleh lembaga media } \\
\text { bersama anggota komunitas. }\end{array}$ \\
\hline $\begin{array}{l}\text { Karakteristik } \\
\text { Operasional }\end{array}$ & $\begin{array}{l}\text { Disiarkan secara luas. } \\
\text { Cenderung satu arah. } \\
\text { Feedback cenderung tertunda. } \\
\text { Sistem operasional rumit dan mahal } \\
\text { Peran narasumber dengan sasaran } \\
\text { terpisah jelas. }\end{array}$ & $\begin{array}{l}\text { Penyiaran terbatas. } \\
\text { Bersifat interaktif. } \\
\text { Feedback cenderung langsung. } \\
\text { Sistem lebih sederhana dan murah. } \\
\text { Sasaran bias menjadi narasumber/ } \\
\text { peran tak jelas. }\end{array}$ \\
\hline $\begin{array}{l}\text { Pengawasan dan } \\
\text { Pertanggung-jawaban }\end{array}$ & $\begin{array}{l}\text { Bergantung pada sistem negara, bisa } \\
\text { pemerintah, pasar/konsumen, atau } \\
\text { komisi dewan khusus. }\end{array}$ & $\begin{array}{l}\text { Anggota komunitas dan perwakilan } \\
\text { yang ditunjuk oleh warga komunitas }\end{array}$ \\
\hline
\end{tabular}

Sumber: Dianalisis dari berbagai sumber (Rachmatie, 2007: 43). 
Karakteristik media komunitas yang tidak bertujuan sebagai media komersial atau mencari laba menjadi kelebihan sekaligus kelemahan bagi radio komunitas. Kelebihan dari radio komunitas adalah isi siarannya disesuaikan dengan kebutuhan informasi dan hiburan bagi para pendengar yang notabene adalah anggota komunitas tersebut, namun disisi lain radio komunitas menjadi kesulitan untuk mendapatkan sumber dana bagi pengembangan radio komunitas. Sehingga sumber dana berasal dari swadaya anggota komunitas itu sendiri.

Radio komunitas masih dipercaya sebagai medium komunikasi yang paling andal melayani kepentingan masyarakat Indonesia di tingkat komunitas.Radio komunitas dimiliki, dikelola, diperuntukkan, diinisiatifkan, dan didirikan oleh sebuah komunitas sehingga sering disebut sebagai radio sosial, radio pendidikan, atau radio alternatif.Dengan demikian, radio komunitas dapat dijadikan sebagai wahana komunikasi milik masyarakat yang potensial untuk melayani kepentingan komunitasnya sendiri. Oleh sebab itu, radio komunitas harus didasarkan pada kebutuhan masyarakat, mendorong kreativitas partisipan, partisipasi maksimal masyarakat yang dilayani, mendasarkan program pada suatu topik atau tema tertentu (Birowo dalam Masduki, 2003: 8687). Rachmatie dalam bukunya menyatakan beberapa pertimbangan perlunya negara memiliki media atau radio komunitas (Rachmatie, 2007: 101):

1. Adanya komunikasi yang lebih demokratis
2. Ketimpangan isi dan infrastruktur

3. Kemajemukan bangsa Indonesia (geografis, agama, etnik, minat)

4. Terbatasnya ketersediaan informasi, khususnya di pedesaan dan tempat terpencil

5. Masyarakat Indonesia yang umumnya merupakan silent majority yang pasif dan rendah aksesnya ke media massa

6. Penguasaan informasi oleh kekuatan tertentu (ekonomi, politik) cenderung lebih meningkat.

Beberapa radio komunitas yang ada di Indonesia seringkali memiliki problem mengenai Sumber Daya Manusia (SDM) pengelolanya. Sebut saja pada kasus Radio Komunitas Angkringan di Timbulharjo, Sewon, Bantul yang memiliki kelemahan pada SDM mereka, dimana SDM atau awak/kru radio tersebut kurang terlatih dan bersifat sukarela (volunteer) serta terdiri dari berbagai profesi dan latar belakang yang berbeda (Hakam, 2011: 16). Padahal, SDM merupakan kebutuhan paling vital bagi radio (Masduki, 2003:80), oleh karena itu radio meskipun dalam sebuah radio komunitas sekalipun, SDM pengelolanya harus memiliki keahlian atau setidaknya mendapatkan pelatihan dalam mengoperasikan radio.

Selain permasalahan SDM, radio komunitas juga menemui permasalahan pendanaan untuk operasional radio mereka.Seperti yang dijelaskan dalam Undang-Undang No. 32 Tahun 2002 pasal 22 bahwa Lembaga Penyiaran Komunitas dapat memperoleh sumber pembiayaan dari 
sumbangan, hibah, sponsor, dan sumber lain yang sah dan tidak mengikat.Radio komunitas juga dilarang melakukan siaran iklan komersial, hanya dapat melakukan siaran iklan layanan masyarakat saja. Maka, radio komunitas dan anggota komunitas tersebut harus mencari cara untuk mendapatkan dana guna menjalankan dan mengembangkan radio komunitas mereka.

\section{B. Konvergensi Radio Komunitas di Indonesia}

Internet tampaknya telah menjadi ruang utama di mana setiap orang dapat berkomunikasi tanpa batasan.Media online seperti blog, situs-situs jejaring sosial dan microblogging memberi peluang bagi setiap orang untuk menciptakan ruang publik tersendiri dan berlangsung secara interaktif secara bebas.Peluang tersebut juga dimanfaatkan oleh radio komunitas di beberapa daerah, yang kini mulai atau bahkan telah melakukan konvergensi media dengan melakukan siaran radio streaming melalui internet.

Konvergensi media sebagai salah satu fenomena yang lahir karena adanya kemajuan ilmu teknologi dan komunikasi.Digitalisasi menjadi hal utama untuk melakukan konvergensi suatu media.Pada dasarnya, konvergensi media dipahami sebagai suatu penggabungan dan perluasan media konvensional ke media digital.
Lahirnya konvergensi menjadi peluang sekaligus tantangan bagi radio komunitas untuk dapat memperluas jangkauan siarannya (Takariani, 2013: 34). Dengan adanya konvergensi media, radio dapat disiarkan melalui internet, begitu juga dengan radio komunitas.Radio komunitas yang telah melakukan konvergensi kemudian menjadi semakin luas jangkauan siarannya, sebab para pendengarnya dapat mendengarkan radio melalui internet tanpa batasan jarak, bahkan bisa jadi radio komunitas tersebut juga didengarkan oleh masyarakat umum yang bukan anggota komunitas mereka.

\section{Regulasi Radio Komunitas}

$$
\text { Penyelenggaraan penyiaran }
$$

komunitas, secara konstitusi mendapatkan jaminan dari pemerintah yang pelaksanaannya diatur dalam regulasi. Berdasarkan perspektif legal-formal, keberadaan radio komunitas dapat diperinci berdasarkan (Rachmatie, 2007: 97):

1. Pengaturan frekuensi dan teknologi siaran

2. Kelembagaan/organisasi

3. Isi siaran

4. Aspek lain, seperti jenis khalayak komunitas dan asosiasi

Berikut dalam tabel digambarkan Undang-Undang dan peraturan terkait dengan keberadaan penyiaran komunitas. 
Tabel 3

\section{Regulasi Keberadaan Media Komunitas Menurut UUD 1945}

\begin{tabular}{|c|c|}
\hline $\begin{array}{c}\text { Domain Publik } \\
\text { (Keberadaan secara Fisik) }\end{array}$ & $\begin{array}{c}\text { Public Goods } \\
\text { (Keberadaan Isi Media Komunitas) }\end{array}$ \\
\hline $\begin{array}{l}\text { 1. Pasal } 33 \text { (3) tentang Penggunaan Ranah } \\
\text { Publik. } \\
\text { 2. Pasal } 28 \text { D (1) tentang Hak Rakyat untuk } \\
\text { Mendapatkan Keadilan (equality rules). } \\
\text { 3. Pasal } 28 \mathrm{H} \text { (2) tentang Equality Rules. } \\
\text { 4. Pasal } 28 \text { I (2) tentang Equality Rules. }\end{array}$ & $\begin{array}{l}\text { 1. Pasal } 28 \text { C (1) tentang Hak Rakyat untuk } \\
\text { Mengembangkan Diri. } \\
\text { 2. Pasal } 28 \text { C (2) tentang Hak Rakyat } \\
\text { Berpartisipasi dalam Pengambilan } \\
\text { Keputusan Politik. } \\
\text { 3. Pasal } 28 \text { E (2) tentang Kebebasan Rakyat } \\
\text { Menyatakan Pikiran dan Sikap. } \\
\text { 4. Pasal } 28 \text { E (3) tentang Kebebasan Rakyat } \\
\text { untuk berpendapat. } \\
\text { 5. Pasal } 28 \text { F tentang Hak rakyat untuk } \\
\text { berkomunikasi dan memperoleh informasi } \\
\text { untuk mengembangkan pribadi dan } \\
\text { lingkungan sosialnya, serta berhak untuk } \\
\text { mencari, memperoleh, memiliki, } \\
\text { menyimpan, mengolah dan menyampaikan } \\
\text { informasi dengan menggunakan segala } \\
\text { jenis saluran yang tersedia. } \\
\text { 6. Pasal 28 I (1) tentang Hak Asasi Manusia } \\
\text { tak dapat dikurangi dalam keadaan apapun. } \\
\text { 7. Pasal 28 I (3) tentang Perlindungan } \\
\text { terhadap Identitas Budaya dan Hak } \\
\text { Masyarakat Tradisional. }\end{array}$ \\
\hline
\end{tabular}

Sumber: Amandemen UUD 1945 (Suryokusumo, dalam Rachmatie, 2007: 97) 
Dalam UU No. 32 tahun 2002 menjelaskan pentingnya fungsi media komunitas bagi bangsa, yaitu: untuk menjaga integrasi nasional, kemajemukan masyarakat Indonesia dan terlaksananya otonomi daerah maka perlu dibentuk sistem penyiaran yang menjamin terciptanya tatanann informasi nasional yang adil, merata dan seimbang. Dalam pasal 21 ayat 1juga dijelaskan mengenai apa yang dimaksud dengan lembaga penyiaran komunitas, salah satunya adalah mengenai jarak jangkauan siar. Sebuah lembaga penyiaran komunitas memiliki jangkauan siar dengan wilayah terbatas.Apabila merujuk pada penjelasan pasal tersebut, maka sebuah lembaga penyiaran komunitas, dalam hal ini adalah radio komunitas, kemudian tidak dapat memperluas jangkauan siar mereka, atau bahkan melakukan konvergensi.

Konvergensi yang dilakukan radio komunitas kemudian bersinggungan dengan salah satu pasal dalam UU No. 32 tahun 2002 pasal 21 ayat 1.Dengan adanya konvergensi radio komunitas melalui internet, maka telah melanggar batasan tersebut, sebab ketika media sudah menggunakan internet dalam pendistribusian konten mereka, maka sudah tidak ada lagi batasan jarak.

Dalam Keputusan Menteri Perhubungan Nomor: KM. 15 tahun 2003 tentang rencana induk (master plan) frekuensi radio penyelenggaraan telekomunikasi khusus untuk keperluan radio siaran FM (frequency modulation) yang telah mengalami beberapa kali perubahan tersebut, seakan-akan meng-anak- tirikan kedudukan penyiaran komunitas yang hanya diberi alokasi frekuensi 3 kanal yaitu kanal 202, 203, dan 204. Tidak lebih dari $1 \%$ dari jumlah alokasi frekuensi FM yang ada, sedangkan untuk radio penyiaran publik dan radio penyiaran swasta mendapat alokasi kanal 1 s/d 201. Penyiaran komunitas mendapat alokasi frekuensi paling akhir dan ujung yang berbatasan dengan frekuensi penerbangan yakni 107,7;109,8; dan 107,9 alokasi ini pun yang di sediakan praktik lapangan-nya banyak digunakan oleh lembaga penyiaran yang didirikan oleh pemerintah daerah atau lembaga negara lain seperti kepolisian (Abda, 2018).

Dalam master plan yang dikeluarkan Menteri Perhubungan tersebut, membagi radio menjadi empat kelas, yaitu kelas A, B, dan C untuk stasiun radio siaran publik dan stasiun radio swasta, sedangkan radio komunitas berada di kelas D. Dalam penjelasan master plan tersebut, hak radio komunitas lebih terbatas dibandingkan dengan radio swasta dan publik (Jonathans, 2006: 211). Dalam pasal 3 ayat 2, disebutkan bahwa Stasiun radio komunitas yang digolongkan dalam kelas $\mathrm{D}$ dengan ERP (kekuatan pemancar) maksimum $50 \mathrm{~W}$, dengan wilayah layanan maksimum 2,5 km dari lokasi stasiun pemancarnya.

Dibandingkan dengan radio publik dan swasta yang digolongkan dalam 3 kelas, Kelas A dengan ERP antara $15 \mathrm{~kW}$ sampai dengan $63 \mathrm{~kW}$, dengan wilayah layanan maksimum $30 \mathrm{~km}$ dari pusat kota; kelas B dengan ERP antara $2 \mathrm{~kW}$ sampai dengan $15 \mathrm{~kW}$, 
dengan wilayah layanan maksimum $20 \mathrm{~km}$ dari pusat kota; dan kelas C dengan ERP maksimum $4 \mathrm{~kW}$, dengan wilayah layanan maksimum 12 $\mathrm{km}$ dari pusat kota.

\section{Reformulasi Regulasi Tentang Penyiaran}

Reformulasi regulasi di bidang penyiaran yang visioner, etis, dan progresif guna memperkuat industri penyiaran nasional secara komprehensif.Karena tuntutan sistem penyiaran yang demokratis dan progresif, yang melibatkan setidaknya tiga bentuk lembaga penyiaran, yaitu lembaga penyiaran publik, swasta, dan komunitas (Wibowo, 2013: 64).

Master plan dalam Keputusan Menteri Perhubungan Nomor: KM. 15 tahun 2003 membutuhkan penjelasan yang lebih rinci. Lahan radio komunitas yang hanya mendapat jatah tiga frekuensi memberi kesan bahwa radio komunitas sebagai radio yang tidak banyak peminat, atau seakan-akan menjadi radio yang tidak memiliki banyak pendengar.Bila kita tengok lagi, apakah mungkin semangat radio komunitas dapat ditampung dalam tiga frekuensi tersebut? (Jonathans, 2006: 212).

Kemudian, menilik pada batasan ERP atau batasan kekuatan pancaran dan angkauan wilayahnya, radio komunitas memiliki ERP maksimum $50 \mathrm{~W}$, dengan wilayah layanan maksimum 2,5 km dari lokasi stasiun pemancar. Sedangkan di kota besar, sebut saja Jakarta, memiliki peluang untuk mendirikan radio komunitas lebih dari satu pada setiap frekuensi dari tiga frekuensi yang dialokasikan untuk radio komunitas tersebut.

adalah adanya keberagaman isi dan keberagaman kepemilikan dalam dunia penyiaran di Indonesia.Namun yang terjadi dalam industri media di Indonesia malah sebaliknya.Media dikuasi oleh beberapa kelompok besar.Oleh karena itu, diharapkan regulasi penyiaran dapat memastikan adanya keadilan regulasi khususnya mengenai kontendan kepemilikan yang berpihak pada kepentingan publik. Regulasi penyiaran dinilai tidak adil oleh para aktivis. Regulasi penyiaran dianggap tidak adil, terlihat dari alokasi frekuensi misalnya, radio komunitas hanya mendapat 3 kanal. Seolah-olah radio komunitas dianaktirikan, dengan pembatasan alokasi frekuensi dan jangkauan siar tersebut.

Dalam perkembangannya, baik media yang bersifat personal maupun publik mengalami pergeseran teknologi sehingga memaksa pemerintah harus selalu menyusun ulang regulasi yang telah atau akan disusun. Sebut saja Undang-Undang No. 32 tahun 2002 telah dibuat oleh pemerintah yang mengatur mengenai regulasi penyiaran di Indonesia, namun pada saat Undang-undang tersebut ditetapkan, teknologi digital belum berkembang seperti pada saat ini, media penyiaran belum banyak menggunakan teknologi digital dalam distribusi siaran mereka. Dalam Undang-Undang No. 32 Tahun 2002 tentang Penyiaran pasal 20, 
Lembaga Penyiaran Swasta hanya dapat menyelenggarakan satu siaran dengan satu saluran siaran pada satu cakupan wilayah siaran.Namun dalam era penyiaran digital seperti sekarang ini, peraturan dalam pasal tersebut sudahtidak relevan lagi karena pada penyiaran digital dalam satu saluran dan satu cakupan wilayah, dapat melakukan banyak siaran.

Regulasi yang dibuat sebaiknya tidak hanya mengikat dalam batasan lokal saja, namun juga dapat mengikat dalam lingkup global.Hal tersebut tentu berkaitan dengan adanya konvergensi yang membuat media menjadi bersifat global.Sebut saja ketika radio komunitas yang dibatasi oleh jangkauan jarak dan frekuensi, ketika melakukan konvergensi melalui internet kemudian tidak dapat diikat oleh regulasi yang seperti tidak dipersiapkan untuk menghadapi perkembangan teknologi digital tersebut.Hal tersebut menjadi tugas berat bagi pemerintah pembuat regulasi untuk membatasi penyiaran dalam dunia konvergensi sekarang ini.

Regulasi yang dibuat oleh pemerintah seakan-akan selalu tertinggal oleh perkembangan jaman.Terlebih mengingat betapa panjang perjalanan suatu rancangan undangundang untuk menjadi sebuah undang-undang yang memakan waktu cukup lama. Maka, regulasi akan selalu ketinggalan jaman, ketika undang-undang disahkan, maka teknologi telah melangkah di depannya. Namun, bagaimanapun juga regulasi tetap diperlukan guna membatasi penyiaran dan akses teknologi yang berpotensi menimbulkan dampak negatif.

Dalam sebuah seminar publik, mantan ketua Pansus RUU Penyiaran, Paulus Widianto, juga mengingatkan karakter undangundang penyiaran. Apakah undang-undang tersebut akan menganut self-regulation atau state-regulation. Dicontohkan seperti Undang-Undang Pers yang cenderung menganut self-regulation, dimana regulasi tersebut memberikan kebebasan pada lembaga pers untuk mengatur dirinya sendiri.Namun berbeda dengan Undang-Undang Penyiaran yang di dalamnya juga mengatur frekuensi sehingga karakternya condong state-regulation. Paulus menyarankan untuk Undang-Undang konvergensi nantinya menjadico-regulation, yaitu merupakan gabungan dari self dan state regulation (http://prasetya.ub.ac.id/berita/Regulasi-

Konvergensi-Media-yang-Melindungi-Publik6787-id.html).

\section{Kesimpulan}

Radio menjadi media yang paling berpeluang memenuhi tujuan-tujuan media komunitas tersebut, khususnya di Indonesia yang wilayahnya sangat luas dan berupa negara kepulauan.Lahirnya radio komunitas di Indonesia seakan-akan menjadi penyelamat bagi mereka yang tinggal di wilayah terpencil atau wilayah blank spot untuk tetap dapat memperoleh informasi. Namun, berbagai regulasi yang membahas mengenai penyiaran baik Undang-undang Nomor 32 tahun 2002 tentang Penyiaran, Peraturan Pemerintah, 
peraturan menteri dan atau peraturan-peraturan lain, dianggap masih belum cukup memberikan perlindungan terhadap publik

Problematika internal yang dihadapi oleh pegiat radio komunitas mengenai SDM dan pendanaan harus segera diatasi dengan melakukan regenerasi kepengurusan dan melakukan pelatihan bagi generasi muda untuk mengoperasikan radio komunitas mereka, serta melibatkan anggota masyarakat dalam setiap kegiatan dan mengenai konten yang ada dalam siaran radio komunitas. Untuk masalah pendanaan, radio komunitas dapat mencari alternative lain, misalnya dengan mengajukan proposal hibah ataupun mengajukan danakepada sponsor, sehingga siaran radio komunitas dapat berjalan lebih optimal.

Revisi UU Penyiaran masih belum juga selesai hingga saat ini. Perihal mengenai kewenangan Komisi Penyiaran Indonesia (KPI), peran pemerintah sampai mengenai konsep digitalisasi. Harapannya, Undang-Undang Penyiaran nantinya mampu menjamin tumbuh dan berkembangnya radio komunitas bersama dengan lembaga penyiaran yang lain. Di sini ada kewajiban pemerintah untuk memfasilitasi tumbuh dan berkembanganya lembaga penyiaran komunitas baik dalam pengembangan kapasitas, teknis dan pendanaan.

$\begin{array}{cccc} & \text { Reformulasi regulasi } & \text { perlu } \\ \text { dilakukan } & \text { demi berkembangnya } & \text { radio }\end{array}$ komunitas. Demi kepentingan publik,jangan sampai regulasi membunuh radio komunitas dengan segala batasan-batasan yang seakan-akan memangkas pertumbuhan radio komunitas di Indonesia. Masyarakat dan para pegiat radio komunitas harus terus mengawal revisi Undangundang No. 32 tahun 2002 serta mengembangkan program dan aktivitas terkait dengan radio komunitas.Adanya sistem kepenyiaran yang memberikan hak warga negara dalam pengelolaan penyiaran merupakan hal yang penting, selain itu media merupakan domain publik, bukan milik negara ataupun perorangan.

Radio komunitas seringkali diidentikkan dengan komunitas pedesaan atau masyarakat perbatasan dan kelompok-kelompok kecil yang selama ini kesulitan atau terpojokkan dalam memperoleh informasi. Oleh sebab itu, perlu adanya aturan dari pemerintah yang khusus mengalokasikan kepentingan warga komunitas pedesaan, untuk bisa mendapatkan hak informasi yang sama dengan warga komunitas perkotaan, baik dari program pembangunan komunikasi maupun informasi lainnya. Pembatasan jarak siar dan frekuensi juga perlu dibuat peraturan tersendiri bagi radio komunitas yang melakukan digitalisasisehingga radio komunitas dapat melakukan konvergensi melalui internet tanpa melanggar regulasi yang ada.

\section{Daftar Pustaka}

Jonathans, Errol. 2006. Socrates di Radio: EsaiEsai Jagat Keradioan. Yogyakarta: Gongplus dan Radio Suara Surabaya Masduki, 2003.Radio Siaran dan Demokratisasi. Yogyakarta: Penerbit Jendela 
Kartika Sari Yudaninggar, Reformulasi Regulasi Radio ...

McQuail, Denis. 2004. Teori Komunikasi Massa: Suatu Pengantar. Jakarta: Erlangga

Rachmatie, Atie. 2007. Radio Komunitas: Ekskalasi Demokratisasi Komunikasi. Bandung:Simbiosa Rekatama Media

Sufi, Rusdi. 1999. Perkembangan Media Komunikasi di Daerah: Radio Rimba Raya di Aceh. Jakarta: Departemen Pendidikan dan Kebudayaan RI

Wibowo, Wahyu. 2013. Kedaulatan Frekuensi: Regulasi Penyiaran, Peran KPI, dan Konvergensi Media. Jakarta: PT Kompas Media Nusantara

Jurnal

Dwiana, Ressi. 2013. Radio Komunitas untuk Pemberdayaan Perempuan. IPTEKKOM, Vol. 15 No. 2, Desember 2013: 117-134 ISSN 1410-3346

Hakam, Ulil. (2011). Konvergensi Media dalam Radio Komunitas. Jurnal IPTEK KOM ,Vol. 3 No. 1 Tahun 2011, hal. 2.

Jurriëns, Edwin. 2003. Radio Komunitas di Indonesia: 'New Brechtian Theatre' di Era Reformasi?.Jurnal Antropologi Indonesia 72, hal 11630.

Masduki. 2004. Perkembangan dan Problematika Radio Komunitas di Indonesia. Jurnal Ilmu Komunikasi
Volume 1, Nomor 1, Juni 2004: 7386

Takariani, SupraptiDwi. 2013. Peluang dan Tantangan Radio Komunitas di Era Konvergensi. Balai Pengkajian dan Pengembangan Komunikasi dan Informatika (BPPKI) Bandung. Vol. 11 No. 1, hal 23-38.

Website

Abda, Iman. 2018. Radio Komunitas dan Alokasi Frekuensi. https://suarakota.or.id/radiokomunitas-dan-alokasi-frekuensi/, diakses 27 November 2018 pukul 13.26

Anonim. 2007. http://jrki.wordpress.com/about/, diakses 27 Desember 2018

Anonim . 2011. Regulasi Konvergensi Media yang melindungi Publik. http://prasetya.ub.ac.id/berita/Regula si-Konvergensi-Media-yangMelindungi-Publik-6787-id.html, diakses 27 Desember 2018

Tashandra, Nabilla. 2017. Tak Kunjung Rampung ini Hambatan Revisi UU Penyiaran.https://nasional.kompas.co m/read/2017/06/10/13001461/tak.kun jung.rampung.ini.hambatan.revisi.uu. penyiaran., diakses 27 Desember 2018 pukul 13.34

Utomo, Wisnu Prasetya. 2016. Sinam Sutarno: Proses Perizinan Radio Komunitas Panjang dan 
Volume 7, Nomer 1, Januari 2019

Melelahkan.http://www.remotivi.or.i

d/wawancara/317/Sinam-Sutarno:-

Proses-Perizinan-Radio-Komunitas-

Panjang-dan-Melelahkan, diakses 27

Desember 2018 pukul 13.42

http://jrki.or.id/?page_id=13, diakses 27

Desember 2018 pukul 13.42

Referensi Lain :

Keputusan Menteri Perhubungan Nomor: KM.

15 tahun 2003

Undang-Undang No. 32 Tahun 2002 Tentang

Penyiaran 